\title{
LEGAL AND ECONOMIC ASPECTS OF THE INTRODUCTION OF EDUCATIONAL CENSUS WHEN VOTING IN THE REPUBLIC OF BULGARIA
}

\author{
Ekaterina Bogomilova ${ }^{3}$
}

Received: 09.10.2020, Accepted: 21.10.2020

\begin{abstract}
In recent years in the Republic of Bulgaria the question on educational qualification for voting has more and more been raised. The topic is quite relevant, especially when the results of the 2019 elections for representatives of the European Parliament and those for local governments report: 1) high number of invalid ballots when choosing a preference without specifying a party, 2) the refusal of voters to vote using machines, 3) the so called "election tourism" from Turkey, and 4) the vote buying. These problems raise the relevance of the role of literacy and education of voters when exercising their constitutional rights.
\end{abstract}

Keywords: educational census, rights and obligations, voting, economic and low.

JEL Codes: K100, H52, I210

\section{Introduction}

The introduction of an educational qualification in voting opposes the Constitution as a basic law of the state, democracy as a form of government, the fundamental rights, and obligations of citizens. The goal of this survey is to identify the advantages and disadvantages of the issues studied and, if possible, to find the balance in the collision of rights and interests, which posse legal and socio-economic component. To achieve this goal, the following tasks are set: first to examine whether what democracy gives is understood and consumed within its borders; second, how well citizens know and exercise their rights and the attitude towards their obligations; and third, to study the social and economic effects of the relation: education, choices, and age. The research will use methods

\footnotetext{
${ }^{3}$ National and Regional Security Department, UNWE, Sofia. Assist. Prof., PhD, e-mail: ebogomilova@unwe.bg, ORCID ID: https://orcid.org/0000-0002-8662-4767
} 
from different scientific approaches: legal analysis, historical review, statistical analysis, and comparative analysis.

\section{Constitutional rights and obligations of Bulgarian citizens within the state}

According to Prof. Rosen Tashev (2010, p. 42) in the book "General Theory of Law", the Constitution is a political and legal document. As a political document it materializes the social contract between society and the state, while as a legal one it is the supreme source of positive law for the state.

On July 13, 1991, after the fall of communism, the Seventh Grand National Assembly adopted the fourth Constitution of the Republic of Bulgaria, which is still in force today. It is the supreme law of the state, defining the basic rights and obligations of citizens and equality between them, people's sovereignty, the rule of law, the free-market economy, the separation of powers as a basis for democracy in pursuit of constitutional principles and desired prosperity.

When looking for an answer to the question of whether the educational qualification should determine the rights of citizens in voting, these rights should be analyzed as defined by the Basic Law. In Chapter Two of the Constitution of the Republic of Bulgaria in Art. 53 item 1 states that "everyone has the right for education". Art. 53 item 2, however, defines education up to 16 years of age as compulsory. It is here, where the first collision takes place having in mind the principles for guaranteeing the rights and freedoms of the citizens under the conditions of democracy.

What does it mean to be educated to vote? Is the education a factor for ability to choose a political direction in the development of the state, or the main problem of representativeness is that a certain group of people that cannot be integrated into society and do not perform their basic social obligations, has the right to set the political direction in the development of the state? The answers to these questions are determined by the form of government - democracy.

Democracy as a political system can exist only if the state bodies that exercise the three main activities - legislative, executive and judicial - are separate and independent. (Tashev, 2010, p. 44)

Constitutional democracy is a system of government based on people's sovereignty, in which the structures of government, powers of government and boundaries of government are defined in a constitution. (Roots of American Government, The Meaning of Democracy) Democracy provides opportunities for effective participation of the citizen in governance; equality of the vote and the exercise of ultimate control over governance. 
If we go back a bit and re-read Plato's "State", considered the most utopian work, the development of the state is based on a society ruled by kingsphilosophers, as Plato himself believes that philosophers are the best state leaders - any government must be built on the foundation of wisdom, education, creativity and innovation. However, it is paradoxical to demand an educational qualification from the voters when there is no such requirement for the same when electing state or local bodies. The point of view of Carl Raymond Popper, a prominent liberal and a philosopher from the English school of the 20th century, a critic of Plato's views, is different. According to him, "Open societies do not support a single view of 'truth', but rather try to establish laws and institutions that allow people with different views to live together in peace." This poses new challenges to any government seeking the right course in defining public policies.

In support of the above, Professor Balamezov raises the constitutional issue of "separation of powers." According to him, state power is a single one only (separation of powers is quite conditional), as the state power is indivisible and only a division of government functions is possible. (Valchev, D.) He also raises the issue of educational qualifications in voting, which will later be used to determine the advantages and disadvantages of the topic.

\section{Suffrage - challenges and opportunities}

Art. 11. Item 1 states that "political life in the Republic of Bulgaria is based on the principle of political pluralism". (Constitution of the Republic of Bulgaria, p. 9)

Electoral qualification is a normative requirement that a person must meet to have active or passive suffrage. There are different types of qualification requirements set in today's modern countries: qualification requirement to obtain a citizenship; requirements for voting; wealth and property requirements; moral requirements; related to the payment of taxes, educational requirements; on the basis of sex; language, etc. Qualification is a restriction here that directly affects the nature of subjective rights, in this case - of suffrage.

Active suffrage consists in the possibility for a person to form his / her will and to vote for a certain candidate or party in the elections. (Drumeva, Em.)

In the elections of 1848 , the right to vote was given only to the male population. Previously, there were other restrictions, such as a property qualification, which allowed only people with property to vote. This led to a government composed only of aristocrats who cared primarily for their own interests. Today it is accepted that the qualifications are inadmissible. To vote, a 
person must meet certain criteria. There are small differences in these criteria in different modern democracies. (Suffrage and political pluralism)

The Belgian Constitution of 1831 stipulates a general property qualification to be a voter. The qualification was abolished in 1893. Universal suffrage was introduced after the end of the First World War. (Drumeva, Em.)

In compare with the developed European countries, Bulgaria introduced universal suffrage with the Tarnovo Constitution, adopted in 1879, but universal suffrage only for men. (Drumeva, Em.)

\section{Legal and economic issues of the exercise of the right to vote in the Republic of Bulgaria}

The economic dimensions and problems of the right to vote based on educational qualifications cannot be considered separately from the other limitations that history provides us with. No further research is needed to conclude that education, proportionately impacts the income of the population, the tax collection, the economic prosperity as a whole and the welfare of the state. As a result, the first demands for a change in the Constitution of the Republic of Bulgaria in recent years and the dispute over whether uneducated citizens have the right to elect state and local bodies arose.

According to the famous teacher and thinker Teodosii Teodosiev, "the vote of the professor and the vote of the illiterate in elections cannot be equal, they should not have the same weight. The illiterate does not read, does not know, is not interested and has no information, but decides the fate of Bulgaria." (Vevesti.bg)

Education is widely recognized as a key factor in why some people vote and others do not. But the essential reasons for this connection remain poorly understood. The benefits of educational qualifications can be seen as increasing voter turnout, which in turn leads to political efficiency. Education makes citizens more capable and motivated to participate in elections, it appears as a resource for electoral activity. In addition to being a resource for electoral activity, it is assumed that educational qualification sets a minimum of economic development and prosperity, through specific demands for future policies.

As a result of the policy of guaranteeing the principles of democracy, during the last 10 years in Bulgaria 4 regular and 3 caretaker governments ruled the state, all formed in response to protests and civil dissatisfaction with the policy related to social and economic prosperity. According to the Constitution of the Republic of Bulgaria, everyone has the right to exercise their right to vote, 
except for persons placed under guardianship or imprisonment when they have reached 18 years of age and are Bulgarian citizens.

In addition, the last elections showed an increase in the number of invalid ballots. The calculations of the Transparency International Association, based on the official results of the local elections in all 265 municipalities, show that at the national level the number of invalid ballots for municipal councillors is a historical maximum of total 466,077 , or $15.098 \%$ of the submitted bulletins. (Transparency International (TI) However, can a connection be sought between education and invalid votes?

The first challenge is the exercise of the right to vote by the Roma population in the country. In the Republic of Bulgaria in the last 30 years, the processes of integration of this group of the population is carried out at a slow pace. The education of these marginalized social groups continues to be fictitious rather than real. There are a number of policies under implementation related to compulsory education linked to the social system, but these has not worked effectively. The Roma as a community is one of the groups emotionally manipulated in voting, a "manipulation" based also on the purchase of votes is a fact, which ranks this social group among the most active groups during elections. If we look at the United States, it can be seen that over the years, their electoral system for black voters has evolved precisely on the basis of literacy, despite the adoption of this principle in different states at different times. For example, the use of a literacy test was a key part of the voter registration process. Although many jurisdictions across the country have used literacy tests, fraud has been used in this registration. Literacy tests were based on interpretations of a complex section of the state's constitution or read from a newspaper written in a foreign language. Some analysts of these texts considered this restriction as racial segregation, especially if the turnout was below 50\%. In 1970, the Nixon administration proposed a suspension of literacy tests as a condition for voting. The 1970 amendments were insignificant compared to those made in 1975. First, Congress extended the provisions of the law to 1982 and permanently banned the use of literacy tests as part of the registration process throughout the country. But the most important change was when Congress put "linguistic minorities" under special protection. (Blum, Ed.) Following the example of the United States, it can be summarized that the literacy barrier is related to the increase of the voting in the country, i.e. it is growing. The main conclusion that can be made is that illiteracy can be manipulated or better known in Bulgaria as "bought" during elections. 
Professor Balamezov also raises the issue of educational qualification when voting in Bulgaria. According to him, Bulgarian citizens should receive voting rights after reaching the age of 23 . At the same time, after the age of 21, he allows every citizen to be a voter and eligible if he "marries, receives higher or special education, opens a cultural, commercial or industrial enterprise on his own." This his proposal he motivates with voting the understanding that it is "absurd" for political capacity to occur earlier, even three years earlier, then civil and commercial capacity. (Doncheva, L.) Here is the place to mention that in Bulgaria the question of the economics of voting arose as early as 1946-1947.

The second challenge is the so called "electoral tourism". The constitution of Republic of Bulgaria stipulates that political parties cannot be formed on ethnic, racial and religious grounds, but in the years of transition $(1990-2020)$ we have witnessed the existence of such political parties. Voters for such parties do not even know the official language of the Republic of Bulgaria, but they are not deprived of the right to vote. The topic of Turkey and the ethnic Turks in Bulgaria is especially relevant in every Bulgarian election. The legal solution here can be sought in whether dual nationals have the right to vote for local (municipal) or even state bodies. This issue is controversial, but it has its economic justification and it can be motivated by the payment of local taxes and fees. It is fair when you exercise your right to vote in order to set a management policy, to have a relationship with the revenue side of the place (certain municipality). Legally, these voters have the full right to vote in elections, as they documented this residency. Address registration is a necessary condition, both permanent and current address on the territory of the country, as at least one of the family must be in the place of voting, on the territory of the respective municipality no less than six months before the elections. The problem is with the control of settlement. Apart from the topic of Turkey, the question of whether Bulgarians living abroad should have the right to vote for European, state and local bodies is also controversial. Again, this issue must be considered in the context of the public goods consumed. The effects of the national policy cannot be considered as benefits beyond the country's borders. But they can be explained with the following interdependencies - the influence of the political institutions on the economic policy by studying the effect of electoral rules on a particular program - for example, tax program, the social program, the educational program. This could lead to overcoming the challenge of transforming the public spending into public goods.

A third challenge faced by the electoral system and related to educational qualifications are the disadvantaged citizens (with physical and other illnesses). 
In principle, the legislator regulates these rights of this social group of citizens and can place them under guardianship. Such cases are observed when there is a person's illness that affects his will (psyche), when this illness has affected the person's ability to be aware of his actions and will. For example, people with Down syndrome, themselves with different mental development, not always may be banned from voting nor educational requirements may be imposed here. These people are actually able to work and they are not banned from the right to vote. In the same time, people who need personal assistance shown with the respective document from the expert medical commission, their vote can be forged.

Therefore, the legislation on the electoral process should be reviewed and amended, based on the constitutionally established rights of citizens.

\section{Conclusion}

As the study does not seek completeness of the issues and challenges identified, the following conclusions can be made:

1. Educational qualification is relevant to the electoral process and can be encouraged with the tax policy of the state.

2. Educational qualification is a resource that has to do with economic development, which is revealed in its connection with the right to vote.

3. Education is a constitutional right and obligation, which is subject to state control and responsibility.

4. The educational qualification requires expenditures for the achievement of public goods.

The educational qualification for the exercising of the right to vote has its legal and economic tangents, but at the same time contradictions. In democracies, these contradictions can be overcome not only by sustainable economic development, but also by rethinking the principles, policies, and rules of elections. 


\section{REFERENCES}

Blum, Ed., The Unintended Consequences of Section 5 of the Voting Rights Act, American Enterprise Institute WASHINGTON, D.C.

Constitution of the Republic of Bulgaria, Annotated with the Interpretative Practice of the Constitutional Court, Ciela Norma AD, Sofia, 2019, p. 9.

Doncheva, L., Professor Stefan Balamezov and the Constitutional Question in Bulgaria 1946-1947, http://webcache.googleusercontent.com/search?q=cache:NHV 4AZi2n0J:jo urnals.uni-vt.bg/getarticle.aspx \% 3Faid\% 3D4804\% 26type\% 3D.pdf + \& $\underline{\mathrm{cd}}=1 \& \mathrm{hl}=\mathrm{bg} \& \mathrm{ct}=\mathrm{clnk} \& \mathrm{gl}=\mathrm{bg}, 18.11 .2019$.

Drumeva, Em., Constitutional Law, https://chitanka.info/text/29884/42

Official site of Vevesti.bg, Politics, Headlines, Teodosii Teodosiev: An educational qualification is needed for voting, otherwise illiterate people decide the fate of Bulgaria, http://vevesti.bg/216836/teodosiy-teodosievnuzhen-e-obrazovatelen-tsenz-za-glasuvane-inache-negramotni-reshavatsadbata-na-balgaria/, 18.11.2019.

Roots of American Government, The Meaning of Democracy, https://dlc.dcccd.edu/usgov1-1/the-meaning-of-democracy, 18.11.2019.

Suffrage and political pluralism, https://www.ago-academy.org/statii/izbiratelnopravo, 18.11.2019.

Tashev, R., General theory of law, basic legal concepts, Sibi, 2010ublic goods.

Transparency International (TI), News, Open letter to the CEC on the invalid votes in the local elections, http://transparency.bg/bg/\%d0\%bd\%d0\%be \%d0\%b2\%d0\%b8\%d0\%bd\%d0 \%b8/\%d0\%be\%d1\%82\%d0\%b2\%d0\%be\%d1\%80\%d0\%b5\%d0\%bd\%d0\% be- $\% \mathrm{~d} 0 \% \mathrm{bf} \% \mathrm{~d} 0 \% \mathrm{~b} 8 \% \mathrm{~d} 1 \% 81 \% \mathrm{~d} 0 \% \mathrm{bc} \% \mathrm{~d} 0 \%$ be- $\% \mathrm{~d} 0 \% \mathrm{~b} 4 \% \mathrm{~d} 0 \%$ be-

$\% \mathrm{~d} 1 \% 86 \% \mathrm{~d} 0 \% \mathrm{~b} 8 \% \mathrm{~d} 0 \% \mathrm{ba}-$

$\% \mathrm{~d} 0 \%$ be $\% \mathrm{~d} 1 \% 82 \% \mathrm{~d} 0 \% \mathrm{bd} \% \mathrm{~d} 0 \%$ be $\% \mathrm{~d} 1 \% 81 \% \mathrm{~d} 0 \% \mathrm{bd} \% \mathrm{~d} 0 \%$ be-

\%d0\%bd\%d0\%b5\%d0\%b4\%d0\%b5\%d0\%b9\%d1\%81\%d1\%82/, 18.11.2019.

Valchev, D., General Theory of the State, Theory of Separation of Powers, http://webcache.googleusercontent.com/search? $\mathrm{q}=$ cache:n6h0GEomFZcJ:d anielvalchev.com/docs/Tema\%25208-OTD18.ppt $+\& \mathrm{~cd}=6 \& \mathrm{hl}=\mathrm{bg} \& \mathrm{ct}$ $=\mathrm{clnk} \& \mathrm{gl}=\mathrm{bg}, 18.11 .2019$. 